\title{
Characterization and Corrosion Resistance Behavior of Shape Memory Stainless Steel Developed by Alternate Routes
}

\author{
David Dias $^{1, *(\mathbb{C})}$, Sandra Nakamatsu ${ }^{2}$, Carlos Alberto Della Rovere ${ }^{3}{ }^{(0)}$, Jorge Otubo ${ }^{1}$ \\ and Neide Aparecida Mariano ${ }^{4}$ \\ 1 Postgraduate Program in Aeronautical and Mechanical Engineering, Aeronautical Institute of Technology, \\ Vila das Acácias, Sao José dos Campos 12200-000, Brazil; otuboj@gmail.com \\ 2 Institute of Physics and Chemistry, Federal University of Itajubá. Av. BPS, 1303-Pinheirinho, \\ Itajubá 37500903, Brazil; sanmitinaka@gmail.com \\ 3 Postgraduate Program in Materials Science and Engineering, Federal University of São Carlos. Rod. \\ Washington Luís, km 235-SP-310, São Carlos 13565906, Brazil; rovere@ufscar.br \\ 4 Postgraduate Program in Materials Science and Engineering, Federal University of Alfenas. Rod. \\ José Aurélio Vilela, Poços de Caldas 11999, Brazil; neideaparecidamariano@gmail.com \\ * Correspondence: david_cta1@hotmail.com; Tel.: +55-12-9155-6887
}

Received: 20 November 2019; Accepted: 10 December 2019; Published: 20 December 2019

\begin{abstract}
The microstructural characterization and corrosion resistance behavior of $\mathrm{Fe}-\mathrm{Mn}-\mathrm{Si}-\mathrm{Cr}-\mathrm{Ni}$ alloy with shape memory effect was studied under different mechanical processing conditions and heat treatments, which were produced using conventional casting and routing methods to reduce costs and make production viable. Microstructural characterization was performed with electron microscopy and x-ray diffraction techniques, electrochemical tests with polarization, and thermogravimetry techniques. The cast condition presented a dendritic structure and the presence of the secondary phases: ferrite- $\delta$ and Chi- $X$ phase. The heat treatment eliminated phases, reincorporated elements in the matrix, and increased the austenitic grain. After the hot rolling process, the alloy exhibited a refined microstructure with recrystallized austenitic grains. The heat-treated condition presented better oxidation resistance than the other conditions, while the hot-rolled condition showed repassivation of the pits, raising them to higher levels. All conditions presented low corrosion resistance in environments containing chloride ions.
\end{abstract}

Keywords: shape memory alloy; stainless steel; corrosion behavior

\section{Introduction}

In recent years, iron-based alloys with a shape memory effect (SME) have received attention as possible candidates to replace superelastic Ni-Ti alloys, which have a high manufacturing cost. In this sense, features such as good workability, machinability, shape recovery (values of 3-5\%), and corrosion resistance make this Fe-Mn-Si-Cr-Ni alloy very attractive for applications such as coupling pipes; hydraulic pipes on aircraft, power plants, and chemical processing plants; connectors for electrical cable; and orthodontic wires. However, raw materials and processing routes increase the cost of the final product, which often makes production unviable [1-4].

Shape memory alloys, after plastic deformation, can recover their original shape or state through suitable heat treatments. This shape recovery property is directly related to the martensitic transformation during deformation $(\gamma \rightarrow \varepsilon)$ and its reversal during heating $(\varepsilon \rightarrow \gamma)$ [5-7].

Traditionally, plastic deformations, through the formation of martensite, have been used to increase the mechanical strength of austenitic stainless steels, which usually have low yield stress. However, 
the strengthening of these steels reduces formability and ductility. To minimize this effect, strengthening can be accomplished through grain refinement, which in addition to improving mechanical strength improves wear resistance, pitting corrosion, and cavitation erosion [8,9].

Soderberg et al. [10] noted that variation in chemical composition, such as increasing manganese $(\mathrm{Mn})$ and decreasing chromium $(\mathrm{Cr})$ contents, has been beneficial in the shape memory effect, but it decreases the generalized corrosion resistance, and cold rolling increases the corrosion current. Maji et al. [11] investigated the influence of microstructural variation on corrosion resistance and found virtually no significant differences in polarization curves, except for a small difference in the passivation threshold. Other research groups found that Fe-Mn-Si-Cr-Ni stainless steel with a shape memory effect exhibited corrosion resistance comparable to AISI 304 austenitic stainless steel in highly oxidizing environments. The protection of the passive film formed in $0.5 \mathrm{M} \mathrm{H}_{2} \mathrm{SO}_{4}$ solution was similar to that of austenitic stainless steel. However, in chloride-containing media, these alloys have localized pitting corrosion. Sulfur-like inclusions and Mn-containing oxides act as active sites for nucleation of corrosion by pits [12-14].

In Fe-Mn-Si-Cr-Ni alloys, the single-phase $\gamma$ microstructure is stable up to $6 \% \mathrm{Si}$ only. Alloys with more than $6 \% \mathrm{Si}$ have a microstructure composed of $\gamma+$ ferrite- $\delta$ phases. The $\mathrm{Fe}_{5} \mathrm{Ni}_{3} \mathrm{Si}_{2}$ type intermetallic phase begins to appear in the microstructure above $7 \% \mathrm{Si}$ and makes these alloys fragile. Si reduces Stack-fault Energy in these alloys, increasing stress-induced martensite nucleation and thus the amount of shape recovery [15].

Recently, researchers subjected Fe-14.29Mn-5.57Si-8.23Cr-4.96Ni alloys to oxidation at $800{ }^{\circ} \mathrm{C}$ and reported that a depleted $\mathrm{Mn}$ ferrite layer emerged between the oxidation layer and the matrix due to selective oxidation of Manganese at high temperatures. The vapor pressure of elemental $\mathrm{Mn}$ is four times greater in magnitude than that of elemental Fe at high temperatures. In other words, elemental Mn vaporizes much more than elemental Fe under vacuum and high temperatures [16].

Hence, this research is fundamentally important for the development of Fe-Mn-Si-Cr-Ni SMA with more economical alternative routes, starting from the scrap metals AISI 304 stainless steel and AISI 1010 low carbon steel, to enable production and obtain attractive properties, such as corrosion resistance, mechanical resistance, and high oxidation resistance. This would be of the significant interest to those working in the fields of stainless steel, contructional materials, energy production, and chemical processes. It would also enrich the literature, optimize processes, and help provide a better understanding of the subject.

\section{Experimental Procedure}

Stainless steel with a shape memory effect was produced in the form of an ingot $15 \mathrm{~cm}$ long and $1.5 \mathrm{~cm}$ wide. Melting in the induction furnace of the AISI 304 austenitic steel scrap, AISI 1010 low carbon steel scrap, and alloying elements such as $\mathrm{Mn}$ and $\mathrm{Si}$, was used to obtain the ingot in the cast condition (CC). The remaining ingot was heat treated for homogenization at a temperature of $1050^{\circ} \mathrm{C}$ for $12 \mathrm{~h}$ with subsequent air cooling and called (HT). Finally, hot rolling in a FENN 55DC2 reversible duo rolling mill at $1100{ }^{\circ} \mathrm{C}$ with $40 \%$ in 16 area reduction passes and subsequent air cooling produced a material that was called (HR). Table 1 shows the values of the chemical composition of the raw materials used and the obtained cast condition ingot, which were determined by optical emission spectrometry, in SPECTROMAX-Spectro equipment (Kleve, Germany). The carbon (C) and sulfur (S) contents were determined by direct combustion in LECO CS-44 equipment, and nitrogen content was determined by thermal conductivity difference (LECO ONH 836) (LECO, St. Joseph, MI, USA). The nominal chemical composition Fe-14Mn-5Si-9Cr-5Ni of the alloy was planned based on the theoretical evidence and experimental results in alloys from the same system [17]. 
Table 1. Chemical composition of raw materials and shape memory stainless alloy (wt. \%).

\begin{tabular}{ccccccccccc}
\hline Materials & $\mathbf{C}$ & $\mathbf{M n}$ & $\mathbf{S i}$ & $\mathbf{C r}$ & $\mathbf{N i}$ & $\mathbf{P}$ & $\mathbf{S}$ & $\mathbf{M o}$ & $\mathbf{C u}$ & $\mathbf{F e}$ \\
\hline AISI 1010 & 0.12 & 0.31 & 0.09 & 0.115 & 0.049 & 0.024 & 0.03 & 0.011 & 0.068 & bal \\
AISI 304 & 0.037 & 1.55 & 0.34 & 17.97 & 8.64 & 0.02 & 0.03 & 0.297 & 0.62 & bal \\
Mn & - & 99.9 & - & - & - & - & - & - & - & - \\
Si & - & - & 99.9 & - & - & - & - & - & - & - \\
CC & 0.06 & 14.7 & 4.19 & 10.24 & 4.63 & 0.017 & 0.02 & 0.17 & 0.41 & bal \\
\hline
\end{tabular}

The sample were prepared to facilitate observation of its microstructure with the optical microscopy (OM) Zeiss model Axio_Imager a2M., Stockholm, Sweden, scanning electron microscopy (SEM) model VEGA3 TESCAN., Brno, Czech Republic, and semi-quantitative energy dispersive spectrum (EDS) Oxford Instruments (Oxfordshire, Abingdon, UK) microanalysis according to ASTM E3-1 standards. Samples were carefully cut with an ISOMET BUEHLER 4000 Diamond disc ISOMET BUEHLERTM (Lake Bluff, IL, USA), sanded with \#2000 SiC paper, polished with METPREP 3 ALLIED (Metprep Ltd., Coventry, UK) automatic polisher with diamond paste of $6 \mu \mathrm{m}, 1 \mu \mathrm{m}, 0.3$ colloidal silica, and metallographic etching with reagents Glyceregia $(20 \mathrm{~mL}$ hydrochloric acid; $15 \mathrm{~mL}$ glycerol; $10 \mathrm{~mL}$ nitric acid) and Villela ( $1 \mathrm{~g}$ Picric acid; $5 \mathrm{~mL}$ hydrochloric acid; $30 \mathrm{~mL}$ ethanol). Ultrasonic baths in acetone and distilled water were used to remove any exogenous impurities from the previous steps. The transformation temperatures of $\mathrm{M}_{\mathrm{s}}, \mathrm{M}_{\mathrm{f}}, \mathrm{A}_{\mathrm{s}}$, and $\mathrm{A}_{\mathrm{f}}$ phases were determined by differential scanning calorimetry (DSC) measured on a Netzsch model DSC 404 C (Selb, Germany) calorimeter using the following conditions: heating to $300^{\circ} \mathrm{C}$ and then cooling to $-100^{\circ} \mathrm{C}$ at a rate $10{ }^{\circ} \mathrm{C} / \mathrm{min}$, purge gases (Argon and Helium) and $\mathrm{N}_{2}$ cooling, respectively. Data were processed using the Netzsch Proteus Thermal Analysis program. Thermogravimetry tests were performed to understand the oxidation resistance of these alloys at high temperatures. These tests involved heating cycles of up to $900{ }^{\circ} \mathrm{C}$ and cooling to room temperature under Ar atmosphere at a heating/cooling rate of $10^{\circ} \mathrm{C}$ $\mathrm{min}^{-1}$ on a Netzsch model STA 449F3 calorimeter. X-ray diffraction (XRD) analysis was performed with $\mathrm{Cu} \mathrm{K} \alpha$ radiation, in a range of $2 \theta$ from $5^{\circ}$ to $90^{\circ}$, with a step of $0.033^{\circ}$ for $2 \mathrm{~s} / \mathrm{step}$, em difratômetro SEIFERT-RAYFLEX. Nuremberg, Germany.

The corrosion behavior was evaluated by the cyclic potentiodynamic polarization method using a potentiostat Autolab/PGSTART 302, da Metrohm, Herisau, Switzerland, connected to a typical electrochemical cell with a saturated calomel electrode (SCE) used as a reference electrode, a platinum plate employed as counter-electrode and the working electrode made from the steel under study. An aerated solution of $3.5 \%$ de $\mathrm{NaCl}$ at room temperature at room temperature $25^{\circ} \mathrm{C}$, was used. After immersion in the solution, the samples were subjected to conditions of open circuit potential (OCP) for $1800 \mathrm{~s}$, and this period of time was enough to stabilize the potential. Tests were performed in triplicates. The polarization curves were obtained by performing a continuous scan with direction reversal when the anodic current density of $10^{-3} \mathrm{~A} / \mathrm{cm}^{2}$ was reached. The scanning speed was constant and equal to $1 \mathrm{mV} / \mathrm{s}$.

\section{Results and Discussion}

Figure 1 presents images obtained by OM and SEM, SEM of the material under the 3 different conditions studied in this article. In Figure $1 \mathrm{a}-\mathrm{c}$, the material is in the cast condition and exhibits a darker phase ferrite- $\delta$, islands of a light phase Chi $(\chi)$ precipitated in interdendritic spaces of the austenitic matrix. Thus, the matrix solidification occurred first, rejecting elements of low solubility to the dendritic spaces, where the secondary phases later solidified. Peng H et al. [18] produced a Fe-Mn-Si-Cr-Ni system alloy and concluded that the effect of Mn is complex. Under certain conditions, it can stabilize other phases in the microstructure such as ferrite- $\delta$. However in the chi phase, while Mo may contribute to its formation, its cubic body-centered structure did not affect the shape memory effect and did not affect the mechanical properties [19-21]. Figure 1d-f illustrate that after the heat treatment, the secondary phases present in the cast condition (ferrite- $\delta$ and Chi- $X$ phase) and the 
martensitic phase disappear, indicating that chemical elements dissolved and reincorporated into the austenitic matrix due to heating at high temperatures, while slow cooling led to nucleation and grain growth. In Figure 1g-i after hot rolling, the alloy presented a refined microstructure and recrystallized austenitic grains.

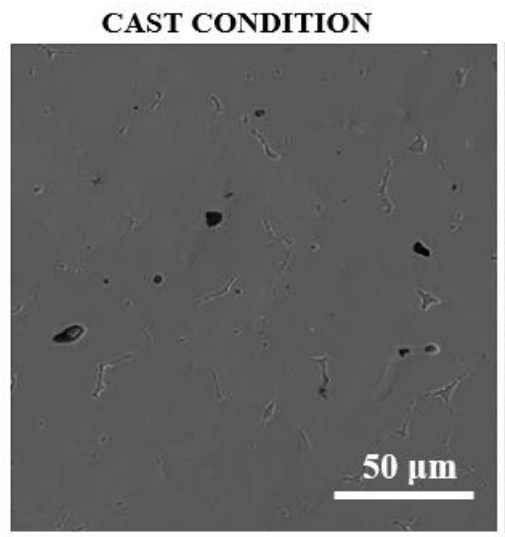

(a)

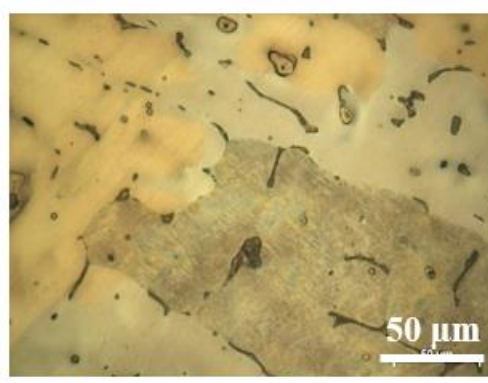

(b)

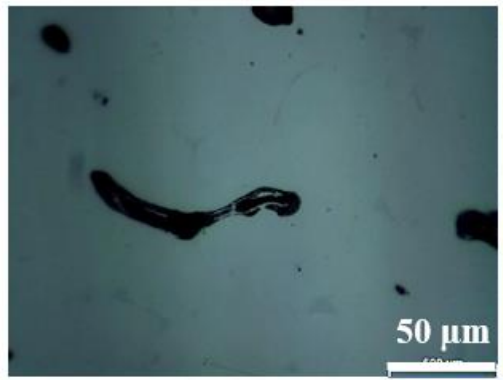

(c)

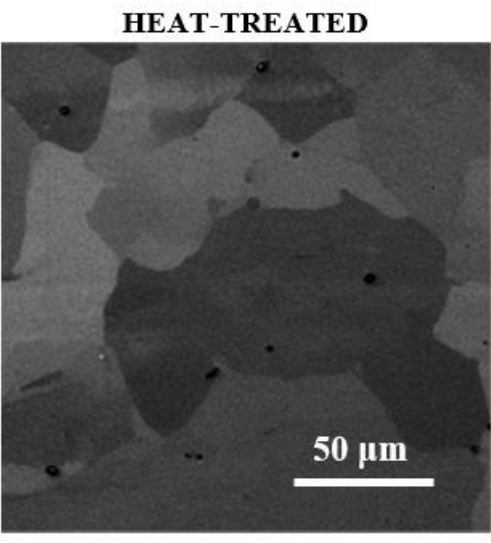

(d)

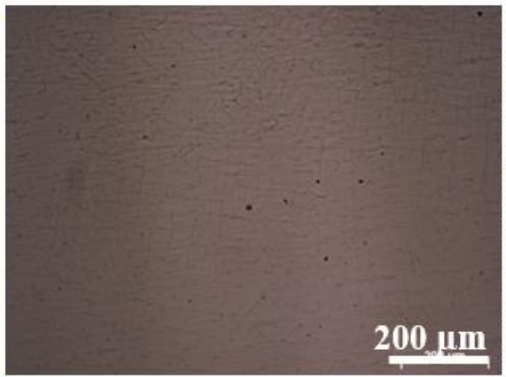

(e)

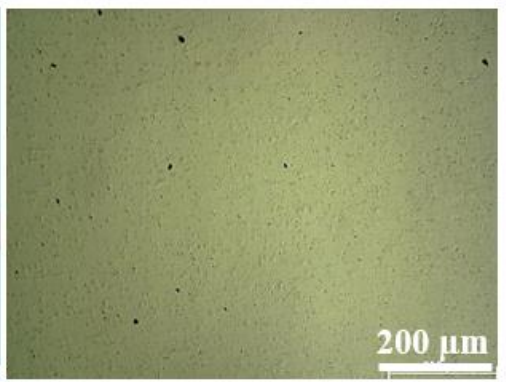

(f)

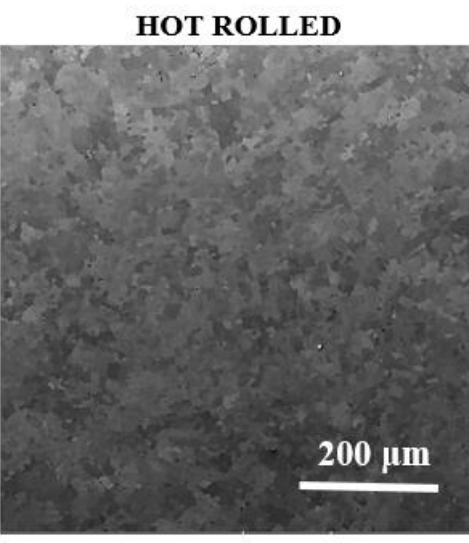

(g)

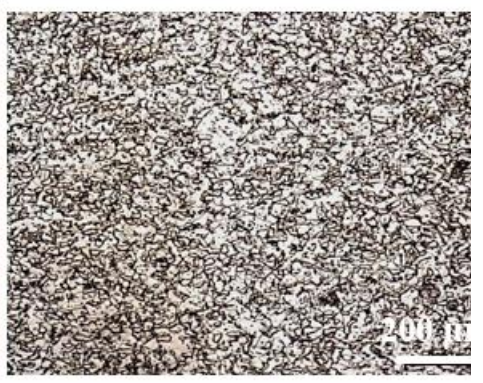

(h)

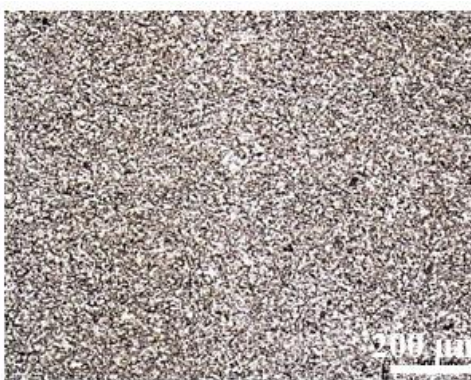

(i)

Figure 1. Images obtained by OM and SEM, SEM after a metallographic attack of Fe-Mn-Si-Cr-Ni alloy with shape memory effect under conditions $(\mathbf{a}-\mathbf{c})$ cast condition, $(\mathbf{d}-\mathbf{f})$ heat-treated, and $(\mathbf{g}-\mathbf{i})$ hot rolled.

The local measurements of EDS microanalysis performed on the cast condition sample for semi-quantitative values of the matrix and inclusions chemichal compositions. These values are presented in Table 2.

The sulfide inclusions are mostly of manganese sulfide (MnS) due to the high Mn content of the alloy. Sulfur, which has a low solubility in steel, has a high affinity for Mn and forms sufficiently high melting point inclusions and stability to prevent network precipitation in the form of films between interdendritic spacings, as occurs with iron sulfide inclusions (FeS). These inclusions have a low melting point and can cause hot cracking in the material during the next steps of thermomechanical processing. The oxide inclusions come from the oxidation reactions of the metallic bath during the 
induction furnace casting process without a protective atmosphere. Also, exogenous inclusions rich in aluminum and silicon occur due to dragging erosion products of the refractory material of the furnace wall and sand mold during the alloy casting process. Normally, non-metallic inclusions are undesirable for the mechanical performance of metallic materials, as they can significantly affect material properties such as ductility, toughness, corrosion resistance, and fatigue life.

Table 2. Chemical composition obtained by Energy Dispersive Spectrum (wt.\%).

\begin{tabular}{cccccccccc}
\hline Element & $\mathbf{F e}$ & $\mathbf{M n}$ & $\mathbf{S i}$ & $\mathbf{C r}$ & $\mathbf{N i}$ & $\mathbf{O}$ & $\mathbf{A l}$ & $\mathbf{C a}$ & $\mathbf{S}$ \\
\hline Matrix & 66.5 & 14.2 & 4.6 & 9.5 & 5.3 & - & - & - & - \\
Inclusion & 5.6 & 28 & 5.0 & - & - & 38.4 & 21.4 & 0.9 & 0.6 \\
Matrix & 64 & 15.6 & 5.2 & 10 & 5.3 & - & - & - & - \\
\hline
\end{tabular}

In Fe-Mn-Si-based alloys, SME is related to non-thermoelastic martensitic transformation $(\gamma \rightarrow \varepsilon)$, and to the fact that close to the temperature $\mathrm{M}_{\mathrm{i}}$ (initial temperature for the transformation of austenite to cooling martensite), a martensite- $\varepsilon$ can also be induced by deformation. The inverse transformation $(\varepsilon \rightarrow \gamma)$ that occurs during heating, reaching the temperature $A_{i}$ (initial temperature for reversal of martensite in austenite) promotes shape recovery. Differential scanning calorimetry (DSC) assays found the transformation temperatures $A_{i}, A_{f}, M_{i}, M_{f}$ phases for the SME alloy. The DSC curves in Figure $2 \mathrm{a}$,b start at low temperature $\left(-100^{\circ} \mathrm{C}\right)$, promote the thermal induction of martensite- $\varepsilon$ in a hot rolled condition, and obtain the temperature $\mathrm{M}_{\mathrm{f}}$. This result indicates that in this condition, the alloy has a greater capacity to form martensite- $\varepsilon$. Table 3 presents the phase transformation temperatures and demonstrates that there was no significant variation in the austenitic $\left(A_{i}\right.$ and $\left.A_{f}\right)$ and martensitic $\left(M_{i}\right)$ transformation temperatures. Some phase transformation peaks were not detected by the technique; thus, the dilatometry technique should be performed to confirm some data.

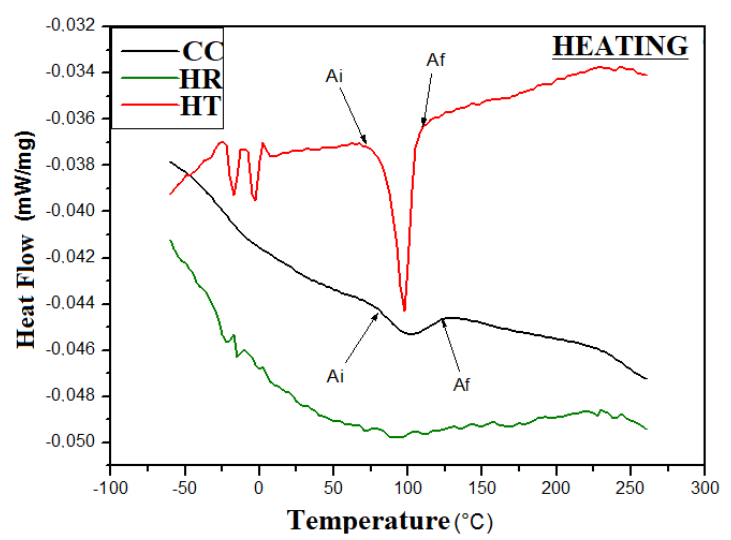

(a)

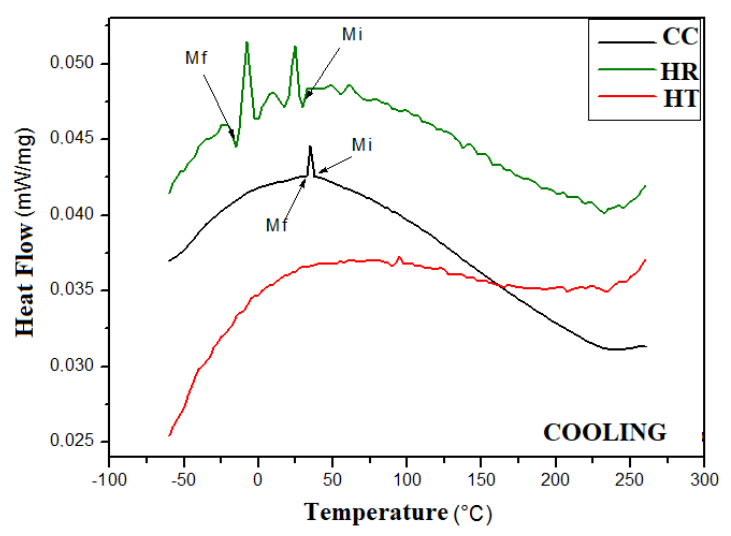

(b)

Figure 2. DSC curves for the samples with SME under all conditions: (a) heating. (b) cooling.

Table 3. Phase transformation temperatures of the alloy with SME in the cast (CC), heat-treated (HT), and hot-rolled (HR) conditions.

\begin{tabular}{ccccc}
\hline \multicolumn{5}{c}{ Temperature $\left({ }^{\circ} \mathbf{C}\right)$} \\
\hline Condition & $\mathbf{M}_{\mathbf{i}}$ & $\mathbf{M}_{\mathbf{f}}$ & $\mathbf{A}_{\mathbf{i}}$ & $\mathbf{A}_{\mathbf{f}}$ \\
\hline $\mathrm{CC}$ & 35 & 30 & 80 & 120 \\
$\mathrm{HT}$ & - & - & 75 & 115 \\
$\mathrm{HR}$ & 30 & -10 & - & - \\
\hline
\end{tabular}

Figure 3a exhibits the potentiodynamic polarization curves in $3.5 \% \mathrm{NaCl}$ solution under the different conditions CC, HT, and HR of the alloy with SME. Table 4 presents the main electrochemical 
parameters: corrosion potential $\left(E_{\text {corr }}\right)$, pitting potential $\left(E_{\text {pit }}\right)$, and protection potential $\left(E_{\text {prot }}\right)$, obtained from the polarization curves. All curves exhibit a typical polarization curve pattern for stainless steels in environments containing chlorine ions with limited corrosion resistance. The alloy with SME, under the conditions CC, HT, and HR did not present a well-defined passive region, making the pitting potential difficult to determine. The HR condition presented the re-passivation of pits increasing to high values. According to the literature [22,23], the corrosion resistance of stainless steel strongly depends on the properties of the passive film formed on the surface, including thickness, chemical composition, compaction, and stability. Pitting corrosion resistance can proceed with the refined microstructure, which can be attributed to the formation of a more stable and compact passive film. Improved corrosion resistance has already been attributed to grain refinement, because surfaces with high grain boundary density have the ability to achieve faster passivation.

The protection potential is the point at which the curve is intercepted after the scan reverses and indicates the potential below which pits passivate form, that is, the pits become inactive, and between the pit potentials $\left(E_{\text {pit }}\right)$ and protection $\left(E_{\text {prot }}\right)$, only the growth of pits that already formed occurs. Conditions HR and HT have $E_{\text {prot }}$ values of $77.8 \mathrm{mV}$ and $140.6 \mathrm{mV}$, respectively. Figure $3 \mathrm{~b}$ illustrates a pit that formed after corrosion testing in $3.5 \% \mathrm{NaCl}$.

According to Ryan et al. [24], the interface between inclusions and the austenitic matrix has a significant depletion of $\mathrm{Cr}$, which makes these regions prone to high dissolution rates and consequently to pitting corrosion. Also, according to Park [25], the increase of Mn content in stainless steel leads to an increase in the number and size of inclusions that contain Mn, which are preferred sites for pitting corrosion, degrading resistance to corrosion in media containing chloride. The effects of Mn in solid solution and its corrosion resistance on Fe-23Cr alloys resulted in decreased passive film resistance through the incorporation of $\mathrm{Mn}$ into the passive film, which resulted in a decrease in the pitting potential value [26]. Also, the passivation potential decreased as the Mn in solid solution increased the dissolution rate of the matrix. Nishimura [27] studied the passive film structure of a Fe-Mn-Si-Cr-Ni alloy system and the crack corrosion resistance in $15 \% \mathrm{NaCl}$ environments, and found that the passive film had two layers, the bottom layer consisted of C (II), Si (II), and Mn (III), and the top of the film contained Cr (III), Si (IV), and Mn (III). Ni was enriched at the interface between metal and film. Cr and $\mathrm{Si}$ were believed to be effective initially, and Ni was effective in preventing crack corrosion penetration.

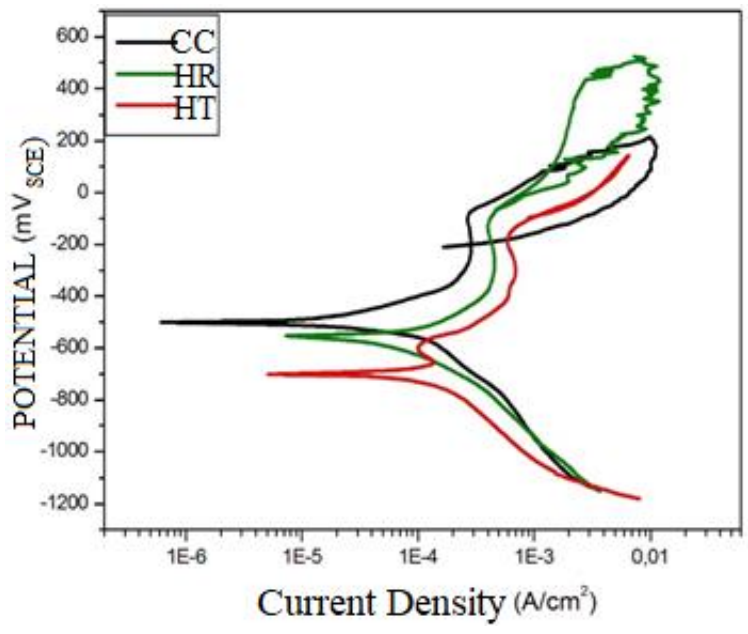

(a)

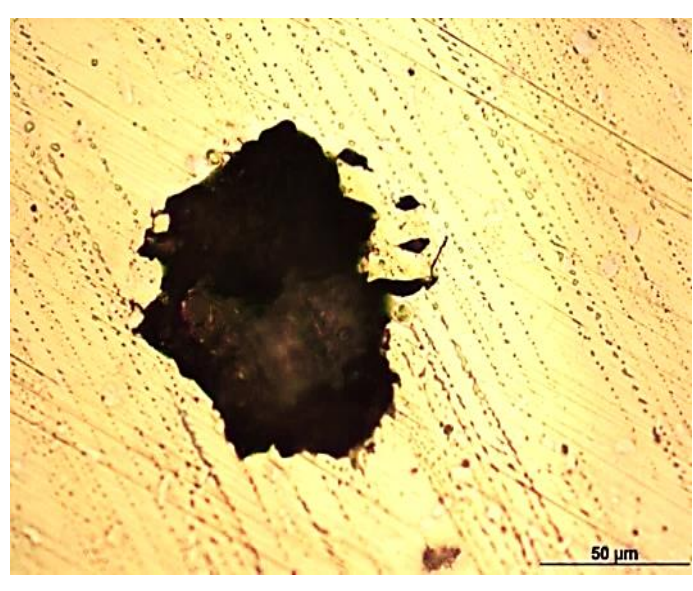

(b)

Figure 3. (a) Potentiodynamic polarization curves in $3.5 \% \mathrm{NaCl}$ for the alloy with $\mathrm{SME}$ under the cast, heat-treated, and hot-rolled condition; (b) Image of pitting corrosion. 
Table 4. Electrochemical parameters for alloy with SME under cast, heat treated, and hot rolled conditions in $3.5 \% \mathrm{NaCl}$.

\begin{tabular}{cccc}
\hline Condition & $E_{\text {corr }}\left(\mathrm{mV}_{\mathrm{SCE}}\right)$ & $E_{\text {pit }}\left(\mathrm{mV}_{\mathrm{SCE}}\right)$ & $E_{\text {prot }}\left(\mathrm{mV}_{\mathrm{SCE}}\right)$ \\
\hline CC & $-445.4 \pm 69.4$ & $-104.1 \pm 54.7$ & $-238.8 \pm 29.5$ \\
HR & $-543.8 \pm 4.9$ & $561.1 \pm 274$ & $77.8 \pm 20.8$ \\
HT & $-694.2 \pm 2.5$ & $-113.5 \pm 23$ & $140.6 \pm 43.4$ \\
\hline
\end{tabular}

TG curves for the different material conditions are in Figure 4. The best performance was for the heat-treated condition, which has mass gains in two stages, before and after $600{ }^{\circ} \mathrm{C}$, suggesting that the oxidation mechanism is different. This may have occurred because ferrite transforms into an austenite phase when the temperature is above about $665{ }^{\circ} \mathrm{C}$ during heating and the presence of a $\mathrm{MnCr}_{2} \mathrm{O}_{4}$ protective layer was observed in XRD analysis. In the hot-rolled condition, the mass gain stabilized at $400-700{ }^{\circ} \mathrm{C}$.

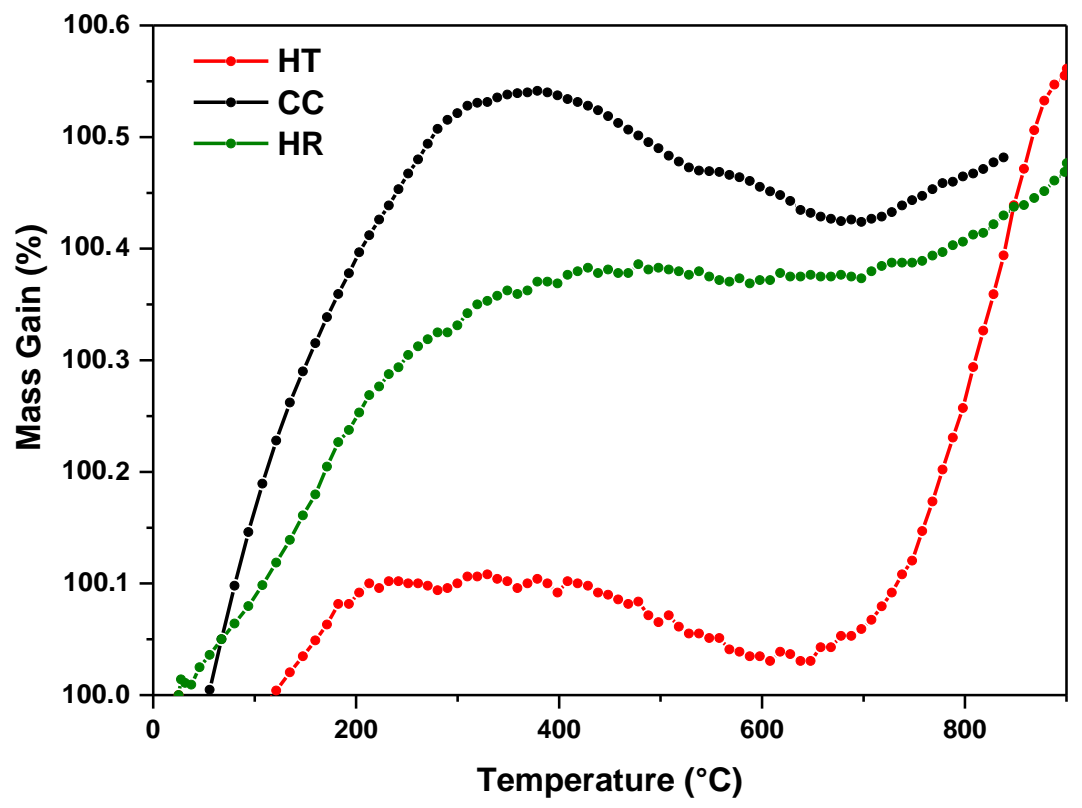

Figure 4. Thermogravimetry curves of all conditions.

When austenitic stainless steels are exposed at elevated temperatures, it is very important to consider the oxidation resistance behavior, which may determine their durability. This behavior depends on the oxide scale formation on the surface. The oxide scale with excellent oxidation resistance should be very stable, slow growing, continuous, free from defects, cracks and pores, adherent, and coherent [16].

Anomalous mass gains during oxidation tests have been found by other research groups [28,29], and finite element analysis is recommended for understanding transformations that occur at such oxidation temperatures. Other studies about materials in the same system found parabolic oxidation curves with the formation of chromium and manganese oxides [30], and that the heat treatment decreased the mass gain rate by two orders of magnitude through the higher formation of protective oxide [31]. The X-ray diffraction analysis, shown in Figure 5, verified that after oxidizing in high temperatures, a mixture of phases, intermetallic phases, and oxides were presented as well as the emergence of the martensitic phase, which is corroborated by other results in the literature. 


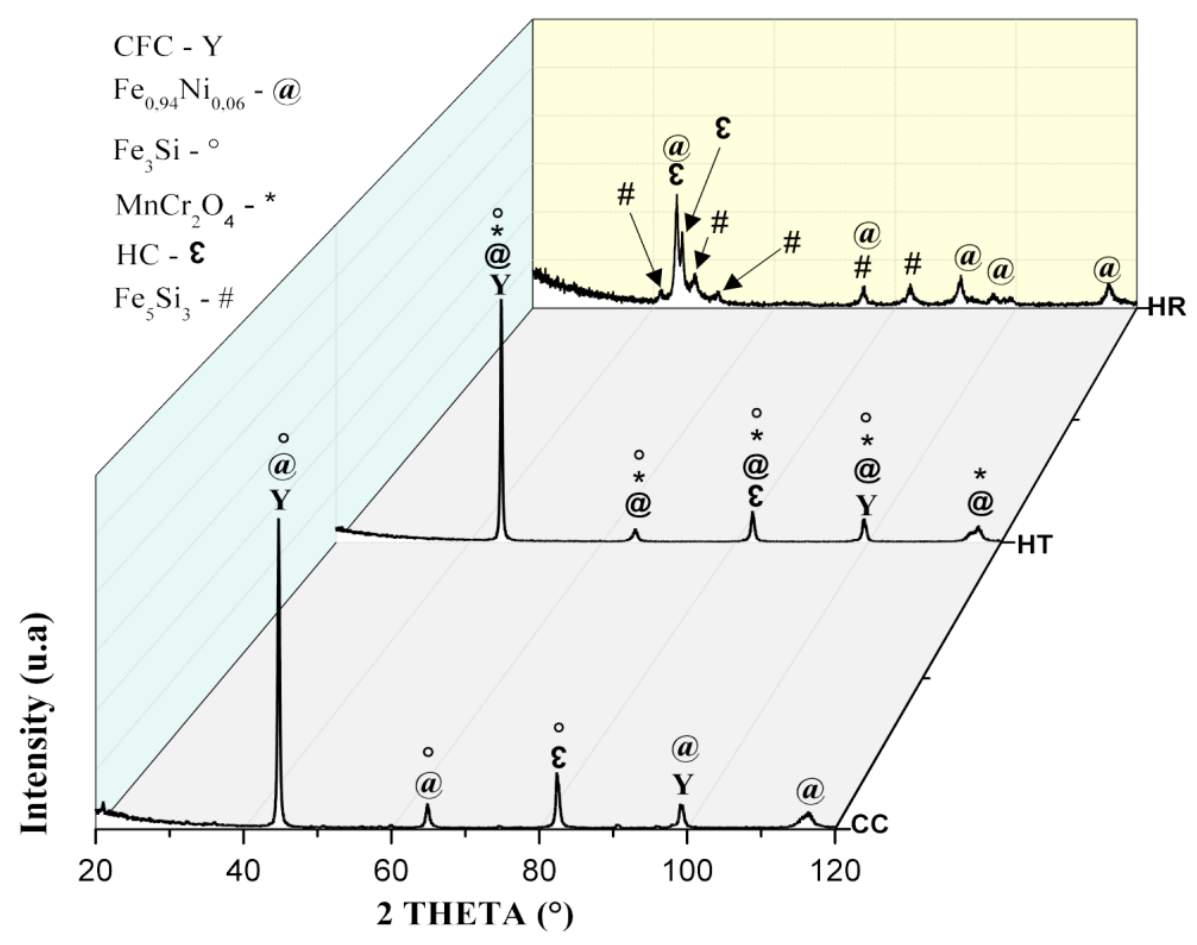

Figure 5. X-Ray Diffractograms obtained after oxidation at $900{ }^{\circ} \mathrm{C}$ in Thermogravimetry tests for the three conditions of the alloys with SME studied in this work.

\section{Conclusions}

The present study conducted microstructural characterization and corrosion resistance behavior of Fe-Mn-Si-Cr-Ni alloy with SME, under different mechanical processing conditions and heat treatments, which were produced using conventional casting and routing methods to reduce costs and make production viable. The cast condition exhibited a dendritic structure and the presence of the secondary phases: ferrite- $\delta$ and Chi-X phase. The heat treatment eliminated phases, reincorporated elements in the matrix, and increased the austenitic grain. After the hot rolling process, a refined microstructure with recrystallized austenitic grains was observed. The heat-treated condition presented better resistance to oxidation than the other conditions. The hot rolled condition presented repassivation of the pits, raising them to higher levels and providing elevated protection potential to higher values. All conditions presented low corrosion resistance in environments containing chlorides.

Author Contributions: Conceptualization, C.A.D.R. and N.A.M.; data curation, D.D., S.N., C.A.D.R. and N.A.M.; formal analysis, D.D., S.N. and N.A.M.; funding acquisition, N.A.M.; investigation, N.A.M. and J.O.; methodology, D.D., S.N., N.A.M. and J.O.; project administration, D.D., S.N. and N.A.M.; resources, C.A.D.R., N.A.M. and J.O.; software, D.D. and S.N.; supervision, S.N. and N.A.M.; validation, J.O.; Writing-Original draft, D.D. and N.A.M.; Writing-Review \& editing, D.D. and N.A.M. All authors have read and agreed to the published version of the manuscript.

Funding: The authors gratefully acknowledge CAPES (Coordination for the Improvement of Higher Education Personnel), FAPEMIG (Minas Gerais Research Foundation) and FAPESP (São Paulo Research Foundation-Grant No. 12/16113-6).

Conflicts of Interest: The authors declare no conflict of interest.

\section{References}

1. Otubo, J.; Borges, F.C.N.; Mei, P.R.; Cardoso, L.P.; Kaufman, M. Influence of austenite grain size on mechanical properties of stainless shape memory alloy. Mater. Trans. JIM 2002, 43, 916-919. [CrossRef]

2. Cladera, A.; Weber, b.; Leinenbach, C.; Czaderski, C.; Shahverdi, M.; Motavalli, M. Iron-based shape memory alloys for civil engineering structures: An overview. Constr. Build. Mater. 2014, 63, 281-293. [CrossRef] 
3. Dai, P.; Zhou, L. Investigation on the connecting strength of Fe-Mn-Si-C shape memory alloy pipe coupling. J. Mater. Sci. 2006, 41, 3441-3443. [CrossRef]

4. Li, J.C.; Lu, X.X.; Jiang, Q. Shape memory effects in a Fe14Mn6Si9Cr5Ni alloy for joining pipe. ISIJ Int. 2000, 40,1124-1126. [CrossRef]

5. Yang, J.H.; Chen, H.; Wayman, C.M. Development of iron based on shape memory alloys associated with FCC to HCP martensitic transformation: Part 1, Shape memory behavior. Metall. Mater. Trans. A 1992, 23, 1431-1437. [CrossRef]

6. Otsuka, K.; Wayman, C.M. Shape Memory Materials; Cambridge University Press: Cambridge, UK, 1998.

7. Verbeken, K.; Van Caenegem, N.; Raabe, D. Identification of $\varepsilon$ martensite in a Fe-based shape memory alloy by means of EBSD. Micron 2009, 40, 151-156. [CrossRef] [PubMed]

8. Lo, K.H.; Shek, C.H.; Lai, J.K.L. Recent developments in stainless steels. Mater. Sci. Eng. R Rep. 2009, 65, 39-104. [CrossRef]

9. Druker, A.V.; Perotti, A.; Esquivel, I.; Malarría, J. A manufacturing process for shaft and pipe couplings of Fe-Mn-Si-Ni-Cr shape memory alloys. Mater. Des. 2014, 56, 878-888. [CrossRef]

10. Söderberg, O.; Liu, X.W.; Yakovenko, P.G.; Ullakko, K.; Lindroos, V.K. Corrosion behavior of Fe-Mn-Si based shape memory steels trained by cold rolling. Mater. Sci. Eng. A 1999, 273-275, 543-548. [CrossRef]

11. Maji, B.C.; Das, C.M.; Krishna, M.; Ray, R.K. The corrosion behavior of Fe-15Mn-7Si-9Cr-5Ni shape memory alloy. Corros. Sci. 2006, 48, 937-949. [CrossRef]

12. Della Rovere, C.A.; Alano, J.H.; Otubo, J.; Kuri, S.E. Corrosion behavior of shape memory stainless steel in acid media. J. Alloys Compd. 2011, 509, 5376-5380. [CrossRef]

13. Della Rovere, C.A.; Alano, J.H.; Silva, R.; Nascente, P.A.P.; Otubo, J.; Kuri, S.E. Characterization of passive films on shape memory stainless steels. Corros. Sci. 2012, 57, 154-161. [CrossRef]

14. Della Rovere, C.A.; Alano, J.H.; Silva, R.; Nascente, P.A.P.; Otubo, J.; Kuri, S.E. Influence of alloying elements on the corrosion properties of shape memory stainless steels. Mater. Chem. Phys. 2012, 133, 668-673. [CrossRef]

15. Maji, B.C.; Krishnan, M.; Ray, G.R.K. Role of Si in improving the shape recovery of FeMnSiCrNi shape memory alloys. Metall. Mater. Trans. A Phys. Metall. Mater. Sci. 2011, 42, 2153-2165. [CrossRef]

16. Ma, R.; Peng, H.; Wen, Y.; Zhang, L.; Zhao, K. Oxidation behavior of an austenitic stainless FeMnSiCrNi shape memory alloy. Corros. Sci. 2013, 66, 269-277. [CrossRef]

17. Li, J.C.; Zhao, M.; Jiang, Q. Alloy design of Fe-Mn-Si-Cr-Ni shape-memory alloys related to stacking-fault energy. Metall. Mater. Trans. A 2000, 31, 581-584. [CrossRef]

18. Peng, H.; Wen, Y.; Du, Y.; Yu, Q.; Yang, Q. Effect of manganese on microstructure and solidification modes of cast Fe-Mn-Si-Cr-Ni shape memory alloys. Metall. Mater. Trans. B 2013, 44, 1137-1143. [CrossRef]

19. Guimarães, R.F.; Figueiredo, N.C.; Pinheiro, V.M.; de Miranda, H.C.; de Abreu, H.F.G. Influência do teor de Mo na microestrutura de Ligas Fe-9Cr-xMo. Soldag. Insp. 2010, 15, 25264. [CrossRef]

20. Stanford, N.; Dunne, D.P.; Monaghan, B.J. Austenite stability in Fe-Mn-Si-based shape memory alloys. J. Alloys Compd. 2007, 430, 107-115. [CrossRef]

21. Fuster, V.; Druker, A.V.; Baruj, A.; Malarría, J.; Bolmaro, R. Characterization of phases in an Fe-Mn-Si-Cr-Ni shape memory alloy processed by different thermomechanical methods. Mater. Charact. 2015, 109, 128-137. [CrossRef]

22. Zheng, Z.J.; Gao, Y.; Gui, Y.; Zhu, M. Corrosion Behaviour Of Nanocrystalline 304 Stainless Steel Prepared By Equal Channel Angular Pressing. Corros. Sci. 2012, 54, 60-67. [CrossRef]

23. Ralston, K.D.; Birbilis, N. Revealing the relationship between grain size and corrosion rate of metals. Scr. Mater. 2010, 63, 1201-1204. [CrossRef]

24. Ryan, M.; Williams, D.E.; Chater, R.J.; Hutton, B.M.; McPhail, D.S. Whys stainless steel corrodes. Nature 2002, 415, 770-774. [CrossRef]

25. Park, K.; Know, H. Effects of Mn on the localized corrosion behavior of Fe-18Cr alloys. Electrochim. Acta 2010, 55, 3421-3427. [CrossRef]

26. Ha, H.Y.; Jang, M.H.; Lee, T.H. Influences of Mn in SOLID solution on the pitting corrosion behaviour of Fe-23 wt\%Cr-based alloys. Electrochim. Acta 2016, 191, 864-875. [CrossRef]

27. Nishimura, T. Crevice corrosion resistance and structure of passive film on Fe-Mn-Si-Cr-Ni steel. ISIJ Int. 2016, 56, 654-660. [CrossRef]

28. Mariano, A.; Malafaia, D.S.; Falcão, M.; Oliveira, D. Anomalous cyclic oxidation behaviour of a Fe-Mn -Si-Cr-Ni shape memory alloy. Corros. Sci. 2017, 119, 112-117. 
29. Mariano, A.; Malafaia, D.S.; Rodrigo, V.; Mendes, L.; Eduardo, M.; Falcão, M. Anomalous cyclic oxidation behaviour of an Fe-Mn-Si-Cr-Ni alloy-A finite element analysis. Corros. Sci. 2019, 147, 223-230.

30. Alberto, C.; Rovere, D.; Mariano, A.; Malafaia, D.S. Kinetics oxidation and characterization of cyclically oxidized layers at high temperatures for FeMnSiCrNiCe and FeSiCrNi alloys. Mater. Res. 2017, 20, 365-373.

31. Mariano, A.; Malafaia, D.S.; Latu-romain, L.; Wouters, Y. High temperature oxidation resistance improvement in an FeMnSiCrNi alloy by Mn-depletion under vacuum annealing. Mater. Lett. 2019, 241, 164-167.

(C) 2019 by the authors. Licensee MDPI, Basel, Switzerland. This article is an open access article distributed under the terms and conditions of the Creative Commons Attribution (CC BY) license (http://creativecommons.org/licenses/by/4.0/). 